\title{
Stratigraphy of Late Quaternary fluvial terraces at the confluence of the Lech and Danube valleys
}

\author{
Patrick Schielein, Gerhard Schellmann, Johanna Lomax
}

Abstract:

\begin{abstract}
The main purpose oft the study is the Würmian Lateglacial and Holocene valley development at the confluence of the Lech and Danube valleys, located in the Northern Alpine Foreland. The morphological features in the study area were surveyed by field mapping and high resolution Digital Elevation Models. The deposits of both rivers were examined in numerous outcrops and dated using radiocarbon and luminescence measurements. Also archaeological data and historical maps were taken into account. The oldest terrace of the valley floor is a Würmian Lateglacial Niederterrasse, which is only prevalent in the Danube valley slightly downstream of the confluence. Fragmentary terraces of Preboreal/Boreal age have been preserved in both valleys and gravel deposits of this age extensively underlie younger terraces. The Atlantic period is not represented by river channel deposits in the study area. In contrast, Subboreal and Subalantic gravel deposits morphologically dominate the lower Lech valley and the Danube valley downstream of the confluence. Up to six Subatlantic terraces accompany the recent courses of Lech and Danube. The distribution and morphological appearance of the Late Subatlantic terraces at the Danube upstream of the confluence refer to a meandering river, whereas the morphology of the youngest Lech terraces predominantly relates to an anabranching river. Downstream of the Lech - Danube confluence the Subatlantic terrace morphology is a transitional one between a meandering and an anabranching depositional setting.
\end{abstract}

\section{[Stratigraphie der jungquartären Flussterrassen am Zusammenfluss des Lech- und Donautals]}

Kurzfassung:

\begin{abstract}
Gegenstand dieser Studie ist die würm-spätglaziale und holozäne Talentwicklung am Zusammenfluss von Lech und Donau im Nördlichen Alpenvorland. Die morphologischen Formen im Untersuchungsgebiet wurden mit Hilfe von Geländekartierungen und digitalen Geländemodellen aufgenommen. Die Ablagerungen beider Flüsse wurden in zahlreichen Aufschlüssen untersucht und deren Alter mit Radiokarbon- sowie Lumineszenzdatierungen bestimmt. Daneben wurden auch archäologische Daten und historische Karten genutzt, um die Altersstellung der einzelnen Terrassen einzugrenzen. Im Untersuchungsgebiet bildet eine spätglaziale Niederterrasse die älteste Flussterrasse innerhalb des Talbodens, die allerdings nur im Donautal unterhalb der Lechmündung erhalten ist. In beiden Tälern sind präboreale bis boreale Terrassenflächen nur kleinräumig verbreitet, während ein Sockelschotter gleichen Alters weiträumig unter jüngeren Ablagerungen anzutreffen ist. Atlantische Flussbettablagerungen sind im Untersuchungsgebiet nicht zu finden. Dagegen dominieren subboreale und subatlantische Terrassen das Lechmündungsgebiet. Die heutigen Flussläufe von Lech und Donau werden von bis zu sechs subatlantischen Terrassen begleitet. Deren Verbreitung und morphologisches Erscheinungsbild verweist im Donautal oberhalb der Lechmündung auf einen mäandrierenden Flusslauf, die der jüngsten Lechterrasse auf ein verzweigtes Gerinnebettmuster. Unterhalb der Lechmündung treten dagegen Übergangsformen beider Flussgrundrisstypen auf.
\end{abstract}

Keywords:

Alpine Foreland, fluvial deposits, valley development, Lech, Danube, Lateglacial, Holocene

Addresses of authors: P. Schielein, G. Schellmann, Physical Geography, University of Bamberg, Am Kranen 1, 96045 Bamberg, Germany. E-Mail: patrick.schielein@uni-bamberg.de; J. Lomax, Institute of Applied Geology, University of Natural Resources and Applied Life Sciences, Peter-Jordan-Straße 70, 1190 Vienna, Austria.

\section{Introduction}

The German Alpine Foreland has been a classic investigation area for the Pleistocene stratigraphy of fluvial and glaciofluvial terraces for more than a century (e.g. PENCK 1882, PENCK \& BRÜCKNER 1909). Nevertheless, there is lack in modern research of Würmian Lateglacial and Holocene river terrace formation in the valleys of the Northern Alpine Foreland with only a few recent regional studies (e.g. MÜNZBERger 2005, MEgies 2006, KocK et al. 2009a, 2009b, SChELLMANN 2010, Gesslein \& SCHELLMANN 2010). As a result, the knowledge of Late Pleistocene and Holocene valley development, and morphological and geological architecture of the fluvial deposits is still fragmentary. Recent developments in airborne laserscanning and the application of numerical dating methods such as AMS- ${ }^{-14} \mathrm{C}$ dating of macroscopic organic material and luminescence dating of fluvial sediments (e.g. KLASEN 2008) have increased the possibilities of reconstructing Lateglacial and Holocene valley development in the Northern Alpine Foreland.

At the confluence of the Lech and Danube rivers, the Middle Pleistocene Rainer Hochterrasse (Fig. 1) was in the focus of previous research (e.g. Graul 1943, SchaEfER 1966, Kilian \& Löscher 1979, Tillmanns et al. 1982, Fiebig \& Preusser 2003), whereas the Late Quaternary valley bottom was examined only by few researchers. Homilius et al. (1983) published a geological map of the Danube valley on a scale of 1:200000, which covers the whole study area, but only distinguishes the youngest floodplain terrace from the surrounding valley floor. Furthermore, geological maps (1:25000) of the northern part of the study area (Grottenthaler, unpublished) and east of the study area (STREIT, 1978) exist. The latter examined mainly Middle and Early Quaternary fluvial deposits of the Danube 


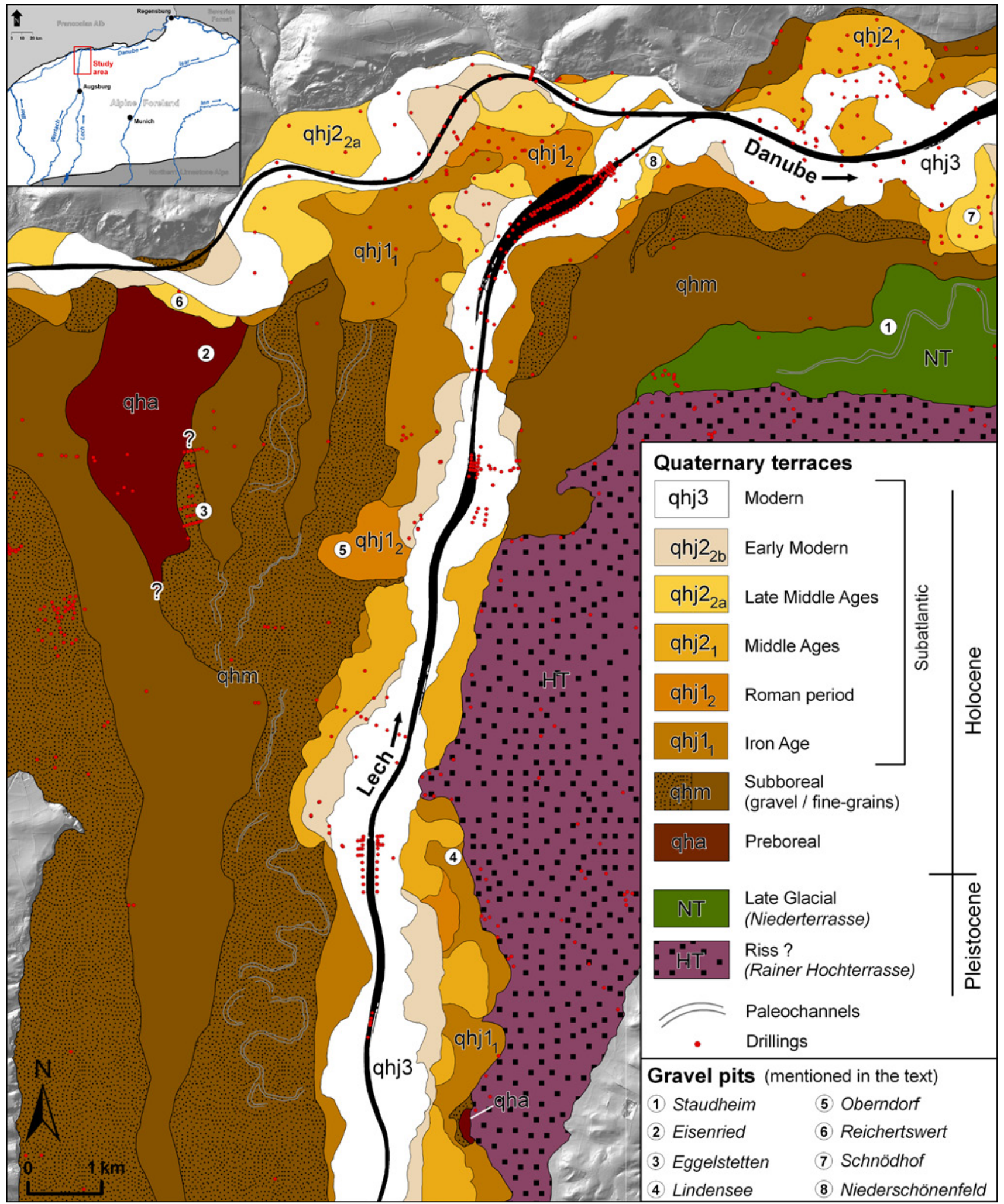

Fig. 1: Distribution, morphology and chronostratigraphy of fluvial terraces and the locations of drillings and examined outcrops in the study area. Abb. 1: Verbreitung, Morphologie und Altersstellung der Flussterrassen und die Lage von Bohrungen und untersuchten Aufschlüssen im Untersuchungsgebiet.

downstream of the Lech - Danube confluence. SchreIBER (1985) investigated the petrography of the Late Quaternary deposits of the Lech valley downstream of the Würmian terminal moraines. He subdivided the Lech valley bottom near the confluence in several levels, which he construed as different alluvial fans.
This regional study focused on Late Quaternary valley development at the confluence of the Lech and Danube. By means of fieldwork, laserscan analysis, numerical dating methods, historical and archaeological data a stratigraphy and chronology of river terraces in both valleys was compiled. The derived reconstruction of the valley develop- 
Tab. 1: Chronology of Late Quaternary river terraces at the Lech - Danube confluence and their age evidences.

Tab. 1: Chronologie der spätquartären Flussterrassen im Lechmündungsgebiet und deren Altersbelege.

\begin{tabular}{|c|c|c|}
\hline River terrace & Age & Numerical age evidence \\
\hline $\begin{array}{l}\text { Young Holocene terrace } 3 \\
\text { [qhj3] }\end{array}$ & $\begin{array}{l}\text { Subatlantic: } \\
\text { Modern Age }\end{array}$ & Historical maps from $19^{\text {th }}$ century. \\
\hline $\begin{array}{l}\text { Young Holocene terrace } 2_{2 b} \\
{\left[q q 2_{2 b}\right]}\end{array}$ & $\begin{array}{l}\text { Subatlantic: } \\
\text { Early Modern Age }\end{array}$ & Historical maps from $18^{\text {th }}$ and $17^{\text {th }}$ century. \\
\hline $\begin{array}{l}\text { Young Holocene terrace } 2_{2 a} \\
{\left[q \text { qhj }_{2 a}\right]}\end{array}$ & $\begin{array}{l}\text { Subatlantic: } \\
\text { Late Middle Ages }\end{array}$ & $\begin{array}{l}1 \text { trunk [prunus] in gravel deposits: } \\
510 \pm 50^{14} \mathrm{C} \text { BP }[650-580 \text { and } 570-480 \text { cal BP]* } \\
\text { Pottery sherd in gravel deposits: } 1300 \text { AD }\end{array}$ \\
\hline $\begin{array}{l}\text { Young Holocene terrace } 2_{1} \\
{\left[q q_{j} 2_{1}\right]}\end{array}$ & $\begin{array}{l}\text { Subatlantic: } \\
\text { Middle Ages }\end{array}$ & Only relative age estimations \\
\hline $\begin{array}{l}\text { Young Holocene terrace } 1_{2} \\
{\left[q \text { hj } 1_{2}\right]}\end{array}$ & $\begin{array}{l}\text { Subatlantic: } \\
\text { Roman period }\end{array}$ & $\begin{array}{l}1 \text { luminescence - age of river sands in gravel deposits: } \\
1.9 \pm 0.2 \mathrm{ka} B P[\mathrm{OSL}] \& 1.6 \pm 0.2 \mathrm{ka} B P[\mathrm{IRSL}]\end{array}$ \\
\hline $\begin{array}{l}\text { Young Holocene terrace } 1_{1} \\
{\left[q \mathrm{qhj}_{1}\right]}\end{array}$ & $\begin{array}{l}\text { Subatlantic: } \\
\text { Iron Age }\end{array}$ & $\begin{array}{l}1 \text { wood fragment in gravel body: } \\
2450 \pm 50{ }^{14} \mathrm{C} \text { BP }[2730-2350 \text { cal BP]* }\end{array}$ \\
\hline $\begin{array}{l}\text { Middle Holocene terrace } \\
\text { [qhm] }\end{array}$ & Subboreal & $\begin{array}{l}3 \text { trunks [juniperus] at the base of gravel deposits: } \\
4130 \pm 60^{14} \mathrm{C} \mathrm{BP}[4840-4510 \text { and } 4470-4440 \text { cal BP]* } \\
3780 \pm 60^{14} \mathrm{C} \mathrm{BP}[4410-3980 \mathrm{cal} \mathrm{BP}]^{*} \\
4290 \pm 50^{14} \mathrm{C} \mathrm{BP}[5040-5010,4980-4810,4760-4700 \text { and } \\
4670-4650 \mathrm{cal} \mathrm{BP}]^{*} \\
\text { Organic material at the base of gravel deposits: } \\
4080 \pm 40^{14} \mathrm{C} \mathrm{BP}[4820-4750 \text { and } 4710-4430 \mathrm{cal} \mathrm{BP}]^{*}\end{array}$ \\
\hline $\begin{array}{l}\text { Early Holocene terrace } \\
\text { [qha] }\end{array}$ & Preboreal & $\begin{array}{l}3 \text { trunks [pinus] in gravel deposits: } \\
9290 \pm 60^{14} \mathrm{C} \mathrm{BP}[10660-10270 \mathrm{cal} \mathrm{BP}]^{*} \\
9360 \pm 70^{14} \mathrm{C} \mathrm{BP}[10760-10370 \text { and } 10330-10290 \mathrm{cal} \mathrm{BP}]^{*} \\
9570 \pm 70^{14} \mathrm{C} \mathrm{BP}[11170-10700 \mathrm{cal} \mathrm{BP}]^{*} \\
\text { Organic material at the top of gravel deposits: } \\
9110 \pm 60^{14} \mathrm{C} \mathrm{BP}[10490-10460 \text { and } 10430-10180 \mathrm{cal} \mathrm{BP}]^{*}\end{array}$ \\
\hline $\begin{array}{l}\text { Niederterrasse }[\mathrm{NT}] \\
\text { Lower terrace }\end{array}$ & Late glacial & $\begin{array}{l}\text { Organic material at the base of the paludal infill of the marginal } \\
\text { depression: } \\
9960 \pm 60^{14} \mathrm{C} B P[11710-11670 \text { and } 11640-11230 \text { cal BP }]^{*}\end{array}$ \\
\hline
\end{tabular}

* calibration of all ${ }^{14} \mathrm{C}$ - ages was carried out with OxCal [curve: INTCALO4; range: 2 sigma]

ment of Lech and Danube will be compared to other reaches of both rivers and to similar confluences in the Northern Alpine Foreland. Moreover, the influence of the Lech on the architecture of floodplain terraces of the Danube will be discussed.

\section{Study Area}

The study area comprises the lower Lech valley and its confluence with the Danube (Fig. 1). The source of the river Lech is located in the Northern Limestone Alps. It is one of four large alpine tributaries (Iller, Isar, Inn) of the Danube in the German Alpine Foreland. The Lech has a length of $264 \mathrm{~km}$ and a catchment area size of c. $3926 \mathrm{~km}^{2}$. At Augsburg, c. $35 \mathrm{~km}$ upstream of the confluence in the Lech valley, the average low water discharge was about $49 \mathrm{~m}^{3} / \mathrm{s}$, the mean discharge $114 \mathrm{~m}^{3} / \mathrm{s}$ and the average high water discharge $594 \mathrm{~m}^{3} / \mathrm{s}$ between 1960 and 2007 (HND 2010). The source of the Danube is situated in the uplands of the Black Forest (Schwarzwald), c. $360 \mathrm{~km}$ upstream of the confluence.
The catchment area of the Danube between its source and the gauge Donauwörth, c. $12 \mathrm{~km}$ upstream of the confluence, amounts to $15092 \mathrm{~km}^{2}$. There, the average low water discharge was about $76 \mathrm{~m}^{3} / \mathrm{s}$, the mean discharge $191 \mathrm{~m}^{3} / \mathrm{s}$ and the average high water discharge $757 \mathrm{~m}^{3} / \mathrm{s}$ in the period 1924-2007 (HND 2010). In the study area, the gradient of the Danube valley amounts to $0.7 \%$, the gradient of the Lech valley to $1.4 \%$. The confluence of both rivers is situated at an altitude of c. $392 \mathrm{~m}$ a.s.l.. It is located in the so called Donauried, a several kilometres broad elongated basin, filled with Late Quaternary fluvial deposits. This basin extends from the mouth of the Iller to c. $10 \mathrm{~km}$ downstream of the confluence, where the Danube cut a narrow valley (Steppberg - Neuburger Talenge) through Jurassic limestone of the Franconian Alb.

The valleys of both rivers are characterized by flights of Quaternary river terraces. The oldest and highest Pleistocene terrace remnants are the Deckenschotter levels, which represent terrace levels related to the pre-Rissian glaciations, deposited in the Middle and Early Pleistocene. 


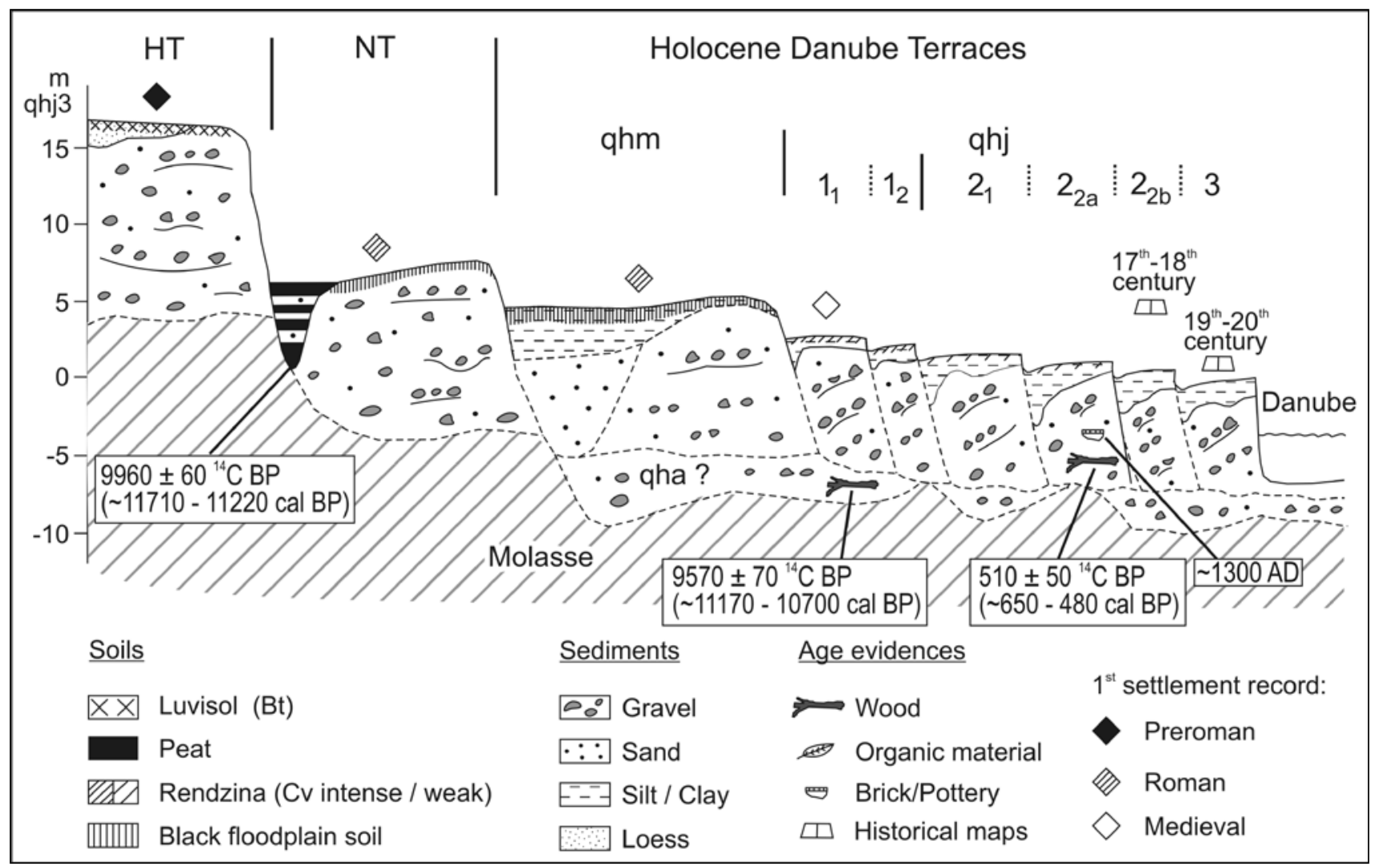

Fig. 2: Schematic cross - section of the Danube valley. Architecture and morphology of Late Quaternary fluvial deposits (compiled on the basis of Digital Elevation Models, field mapping, drilling cores and outcrops) and their age evidences in the Danube valley upstream and downstream of the Lech - Danube confluence at the study area.

Abb. 2: Schematisches Querprofil des Donautals. Aufbau und Morphologie der jungquartären Terrassenkörper (konstruiert aus digitalen Geländemodellen, Geländekartierungen, Bohrdaten und Aufschlüssen) und deren Altersbelege für das Donautal oberhalb und unterhalb der Lechmündung im Untersuchungsgebiet.

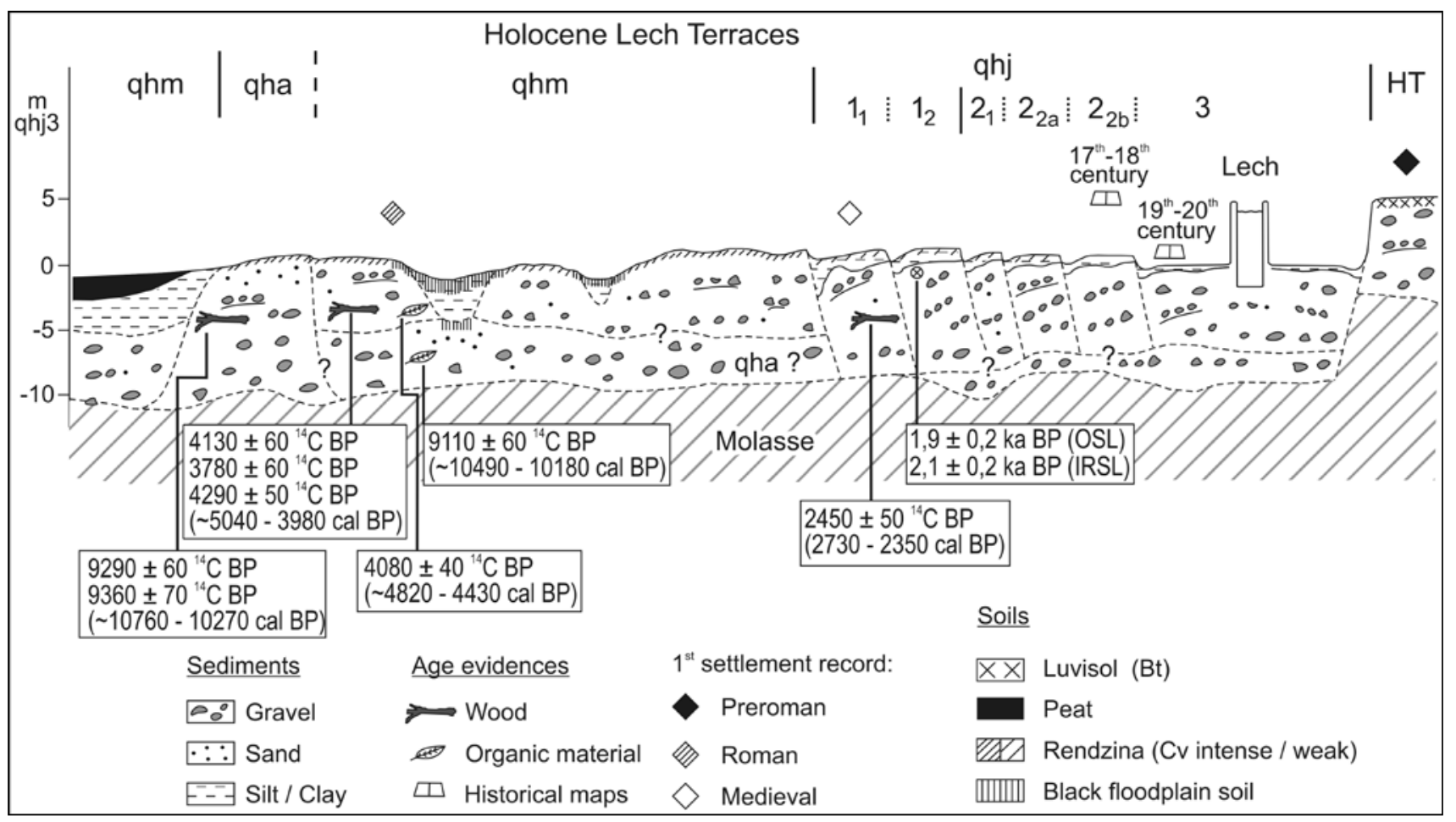

Fig. 3: Schematic cross - section of the Lech valley. Architecture and morphology of Late Quaternary fluvial deposits (compiled on the basis of Digital Elevation Models, field mapping, drilling cores and outcrops) and their age evidences in the Lech valley at the study area.

Abb. 3: Schematisches Querprofil des Lechtals. Aufbau und Morphologie der jungquartären Terrassenkörper (konstruiert aus digitalen Geländemodellen, Geländekartierungen, Bohrdaten und Aufschlüssen) und deren Altersbelege für das Lechtal im Untersuchungsgebiet. 
The less elevated Hochterrassen (HT), with surfaces several tens of meters below those of the Deckenschotter levels, relate to the Riss glaciations since PENCK \& BRÜCKNER (1909). At levels 5-10 meters below, Niederterrassen (NT) of Upper Würmian age are common in the Danube valley, in the middle reaches of the Lech valley and in many other valleys of the Alpine Foreland, but along the river Lech's lower reaches, these are rarely conserved. Instead, terraces of Holocene age make up widespread areas of both rivers' valley floors (Fig. 1, 2, 3).

\section{Methods}

The morphological features were surveyed by field mapping, aided by high resolution digital elevation data (LIDAR, $2 \times 2 \mathrm{~m}$ footprint, at least $0.2 \mathrm{~m}$ vertical resolution) from the OfFice for Surveying AND GeoinformaTION (Landesamt für Vermessung und Geoinformation. Munich, Germany). The mapped sequence of river terraces has been morphostratigraphically differentiated by surface elevation, where possible. If terrace surface elevation differences are small (e.g. decimetres instead of meters), they were differentiated either by a distinct terrace edge at their external seam channel or by morphological unconformities of floodplain channels (following methods outlined in SCHIRMER 1983). The official abbreviations for the different Holocene terraces, defined by the BAVARIAN ENVIRONMENTAL Agency (Bayerisches Landesamt für Umwelt, LFU. Munich, Germany), were used in the geological map (Fig. 1), in the schematic cross sections (Fig. 2, 3) and are also mentioned in the text. A summary of all terraces is shown in Tab. 1. The sedimentology of the Late Quaternary river terraces was investigated in eleven outcrops exposed in gravel pits at the Lech - Danube confluence, of which eight are mentioned in this paper (Fig. 1). More than 800 drillings of different federal agencies and gravel pit operating companies were analysed for the thickness of the Quaternary deposits (Fig. 1). Several dozen cores from finegrained clastic deposits were taken manually. To establish an absolute chronology of the deposits, numerical dating methods were applied on suitable materials from cores and outcrops. Organic material such as wood, charcoal and plant detritus was AMS - radiocarbon dated by Beta Analytic (Miami, USA). All ${ }^{14} \mathrm{C}$-ages were calibrated with OxCal software (Bronk, RAmSEY 1995), using the INTCAL 04 curve (REIMER et al. 2004). Luminescence dating was carried out at the Institute of Applied Geology, University of Natural Resources and Life Sciences (Vienna, Austria). OSL and IRSL ages of the quartz and the feldspar fraction were determined on small aliquots using single aliquot regenerative dose protocols (MurRay \& WintLe 2000, WALlinga et al. 2000). All but two samples were dated using the coarse grain fraction. The remaining two were dated with IRSL signals of the polymineral fine grain fraction. For further details on the luminescence dating procedures see LoMAX \& Schielein (accepted). Archaeological data about historical streets and settlements was provided by the Bavarian State Department of Historical Monuments (Bayerisches Landesamt für Dekmalpflege. Thierhaupten, Germany). Historical maps since the $16^{\text {th }}$ century yielded ages for the aggradation of the two youngest Holocene terraces and al-

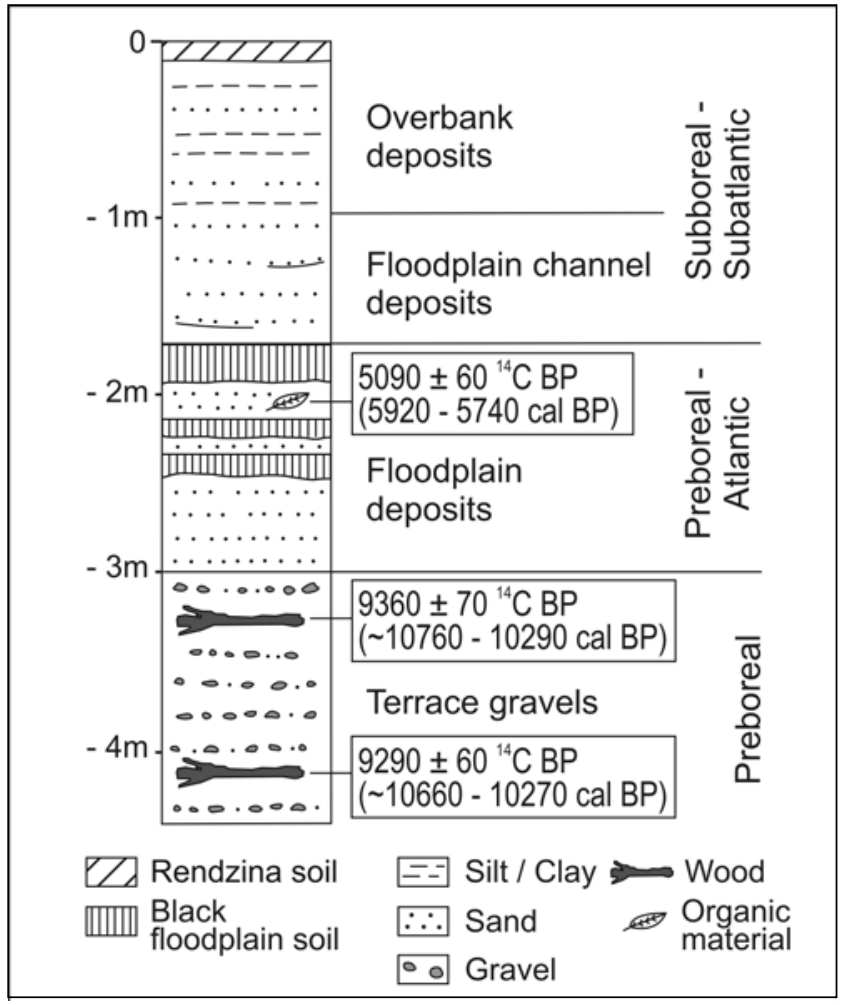

Fig. 4: Profile of the Preboreal terrace (qha) at the gravel pit Eisenried. Abb. 4: Profil der präborealen Terrasse (qha) in der Kiesgrube Eisenried.

lowed the analysis of the relocation of river channels in this period (SCHIELEIN 2010).

\section{Results}

Niederterrasse level (NT)

In the Danube valley, just downstream of the Lech mouth a patch of Niederterrasse is preserved (Fig. 1). The surface is up to $3 \mathrm{~m}$ higher than adjacent Holocene terraces to its north. Its southern fringe is formed by a marginal depression (Randsenke) directly at the slope of the Rainer Hochterrasse (Fig. 2). The valley of the Kleine Paar river and a periglacial dry valley (Dellentälchen) on the Hochterrasse open to the marginal depression. The periglacial dry valley can be connected to a small winding channel crossing the surface of the Niederterrasse approximately parallel to the Danube valley. This channel is not a paleochannel of the rivers Danube or Lech, but originates as a local stream draining the Hochterrasse. The Niederterrasse is composed of sandy gravels with a thickness of up to $13 \mathrm{~m}$. It exhibits only partially a thin cover of floodplain deposits, which consist of horizontally stratified layers of sand and finer grains. The gravels in the small gravel pit Staudheim (Fig. 1) show a strong weathering in the upper part of the outcrop. Plant remains from the base of a paludal infill of the marginal depression (Randsenke) at a depth of $6.5 \mathrm{~m}$ yielded an age of $9960 \pm 60{ }^{14} \mathrm{C} \mathrm{BP}(11610-11220 \mathrm{cal} \mathrm{BP})$ (Fig. 2). This patch of Niederterrasse was last-active in the last millennia of the Pleistocene (including the Younger Dryas), as the channel fill is younger than the fluvial deposition of the terrace sediments, and more or less dates the abandonment of this part of the floodplain by Danube channels. 


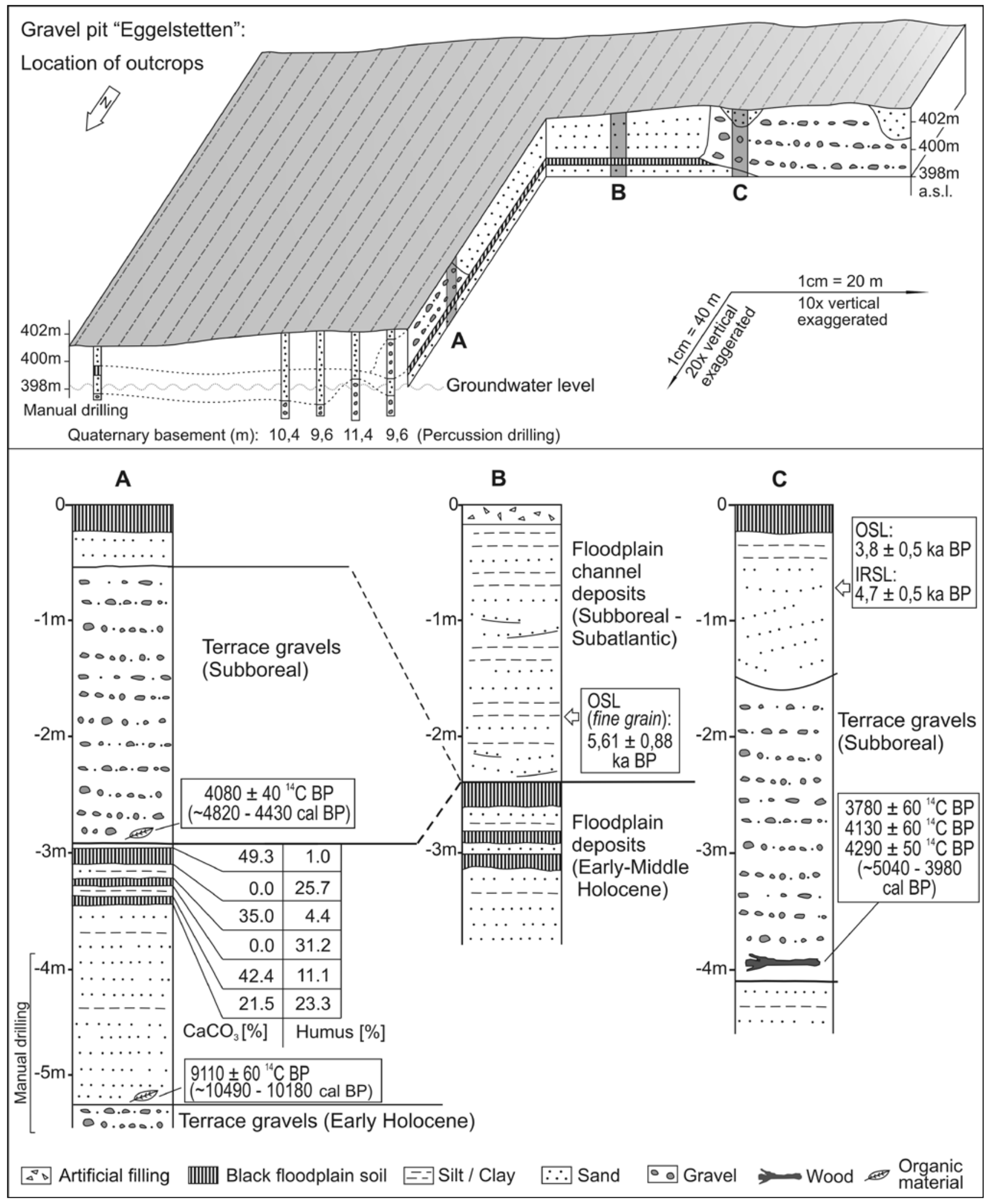

Fig. 5: Profiles of the Subboreal terrace ( $\mathrm{ghm}$ ) at the gravel pit Eggelstetten. Abb. 5: Profile der subborealen Terrasse ( $\mathrm{ghm}$ ) in der Kiesgrube Eggelstetten.

Preboreal terrace level (qha)

Upstream of the river confluence, Early Holocene ' $q h a$ 'terrace remnants are preserved in both the Lech valley and the Danube valley. In the pit Eisenried (Fig. 1) along the Danube, the terrace gravels are covered by fine-grained floodplain sediments with a thickness of up to $3 \mathrm{~m}$ (Fig. 4).
These floodplain deposits are divided by an erosional unconformity. The sediments above the unconformity are composed of sand-striped floodplain channel fill and loamy overbank deposits of Subboreal (2.5-5 ka BP, MANGERUD et al., 1974) or Subatlantic (0-2.5 ka BP, MANGERUD et al., 1974) age. The predominantly sandy floodplain deposits be- 
low the unconformity contain up to three fossil black floodplain soils ("Pechanmoor" sensu BrunNACKer 1957). Organic material from between the two uppermost fossil soils yielded an AMS ${ }^{14} \mathrm{C}$-age of $5090 \pm 40{ }^{14} \mathrm{C}$ BP $(5920-5740 \mathrm{cal}$ $\mathrm{BP})$. Two pine trunks from the underlying gravel deposits, dated to $9290 \pm 60{ }^{14} \mathrm{C} \mathrm{BP}(10660-10270 \mathrm{cal} \mathrm{BP})$ and $9360 \pm 70$ ${ }^{14} \mathrm{C}$ BP (10760-10370 cal BP), indicate a Preboreal (10-9 ka BP, MANGERUd et al., 1974) or, in the event of an later deposition of the trunks, a younger age of the gravels. The gravel deposits in the pit Eisenried are dominated by alpine limestones and dolomites as it is typical for the Lech valley. Jurassic limestones from the Franconian Alb indicate the influence of the Danube river.

In the study area, Preboreal gravel deposits also underlie younger terraces of the rivers Lech and Danube. SCHREIBER (1985) already described in the pit Eggelstetten (Fig. 1) two stacked gravel bodies: The overlying one is composed of carbonatic, alpine gravels with a low amount of crystalline material and can be termed as "Lech facies". In contrast, the underlying gravel body contains a relatively big amount of uncommon material for the Lech valley, such as basalt, lydite and jurassic limestone, and can therefore be related to the influence of the Danube ("Lech - Danube facies"). Whereas the overlying gravels build up the Subboreal terrace (see below), the underlying gravels were denoted as glacio-fluviatile deposits by SCHREIBER (1985). But during our investigations, organic material from the top of the underlying gravel deposits was dated to $9110 \pm 40{ }^{14} \mathrm{C}$ BP ( 10490-10180 cal BP), i.e. to the Preboreal (Fig. 2, 5, Tab. 1). At the outcrop Schnödhof (Fig. 1, 2, Tab. 1), a pine trunk from the gravel deposits, underlying the Subatlantic terrace, yielded an age of $9570 \pm 70{ }^{14} \mathrm{C} \mathrm{BP}(11170-10700 \mathrm{cal}$ $\mathrm{BP})$ and dates the gravel deposition at most to the Preboreal. In drilling cores the thickness of the Holocene fluvial deposits ranges from 7 to $14 \mathrm{~m}$. It can be assumed that the largest amounts of thickness are reached when Preboreal gravel deposits underlie younger terraces, as the base of any other terrace in the study area is significantly higher than that of Preboreal deposits (Fig. 2, 3). Moreover, a couple of these cores show a partition of the gravel deposits by layers of fine-grained sediments and peat. Most probably, this drilled sequences are comparable to that at the gravel pit Eggelstetten with floodplain deposits of up to $2 \mathrm{~m}$ thickness, containing three fossil black floodplain soils between both gravel bodies (Fig. 5).

\section{Subboreal Terrace level (qhm)}

The Subboreal terrace is the most widespread one at the Lech - Danube confluence. It takes up large areas in the lower Lech valley and in the Danube valley downstream of the confluence. The surface of the terrace in the northern part of the Lech valley is characterized by some hundred meters wide, elongated ridges containing meandering paleochannels (Fig. 1). The ridges are separated by two, 1-2 m lower lying depressions, which originate from meandering paleochannels on the less undulated $\mathrm{qhm}$ - terrace surface further up the valley (Fig. 1). The depressions widen up to an extent of $1 \mathrm{~km}$ down the valley. Another broad depression limits the westernmost ridge of the Subboreal terrace (Fig. 1). The channels and depressions represent paleo-river beds of the Subboreal Lech. They were filled with fine-grained material during flood events afterwards. Most probably, the paleochannels of the Lech River were not active simultaneously, but rather mark different stages of an migrating Lech river during the Subboreal. A chronological reconstruction of the migration and hence a subdivision of the Subboreal terrace is hitherto not possible, due to the lack of numerical ages from the different ridges.

Outcrops in the gravel pit Eggelstetten exhibit the stratigraphy of both morphological units (Fig. 1, 5). The exposed depression (profile B) is filled with sandy and finer-grained floodplain channel deposits, reaching a maximum thickness of $5 \mathrm{~m}$. Below them, a stack of three fossil black floodplain soils in overbank deposits is preserved. These fossil soils are low in or free of calcium carbonate and contain a relatively high amount of humus (Fig. 5). They are divided by thin layers of calcareous, loamy floodplain deposits.

The lithology of the ridges is dominated by sandy gravels, which are approximately $3 \mathrm{~m}$ thick. Sand-filled floodplain channels are embedded in the gravel body at many places (profile C). Beneath the Subboreal gravels, older floodplain deposits with a similar fossil soil sequence as in profile B can be preserved (profile A). The Preboreal gravel deposits described above are following thereunder. Organic samples from the base of the overlying gravel body, returned several ages (Tab. 1, Fig. 5) around $4000{ }^{14} \mathrm{C} \mathrm{BP}$ ( 5040-3780 cal BP). They date the terrace formation to the Subboreal. The underlying gravels were deposited during the Preboreal (see above). Infills of several floodplain channels on the Subboreal terrace were dated by OSL and IRSL to 5 to $3 \mathrm{ka} \mathrm{BP}$, whereas the polymineralic fine-grain luminescence age in profile $\mathrm{B}$ is discarded due to the overestimation compared to the ${ }^{14} \mathrm{C}$ ages from the gravel body (LomAX \& SchiElein; accepted). In addition, Roman settlements on the surface and the course of a Roman street, which traverses the full terrace width, are evidences for the abandonment of this area by the river Lech prior to Roman times. Earlier assumed timing of sediment accumulation during the Roman period (SCHREIBER, 1985) is not supported by our data.

In the Danube valley upstream of the Lech confluence region, Subboreal terraces have not been widely preserved. Their extent is much smaller than that of the Subboreal terrace along the lower Lech and the Danube River downstream of the confluence (Fig. 1).

\section{Subatlantic Terrace levels (qhj)}

The youngest valley floor can be subdivided into up to six terraces, which accompany the recent courses of the Lech and the Danube River downstream of the confluence. Upstream of the confluence, only four Danube terraces of Subatlantic age are prevalent. A complete sequence of Late Holocene terraces is preserved in the area between both rivers directly upstream of their confluence. In other parts of the study area only remnants of this terrace sequence are preserved (Fig 1.). The chronology of terraces with age evidences of each terrace is shown in Tab 1.

All Late Holocene terraces are composed of sandy gravels, which are covered with fine-grained floodplain deposits. The thickness of the Late Quaternary deposits in the Subatlantic valley floor ranges from 9 to $13 \mathrm{~m}$. Layers 


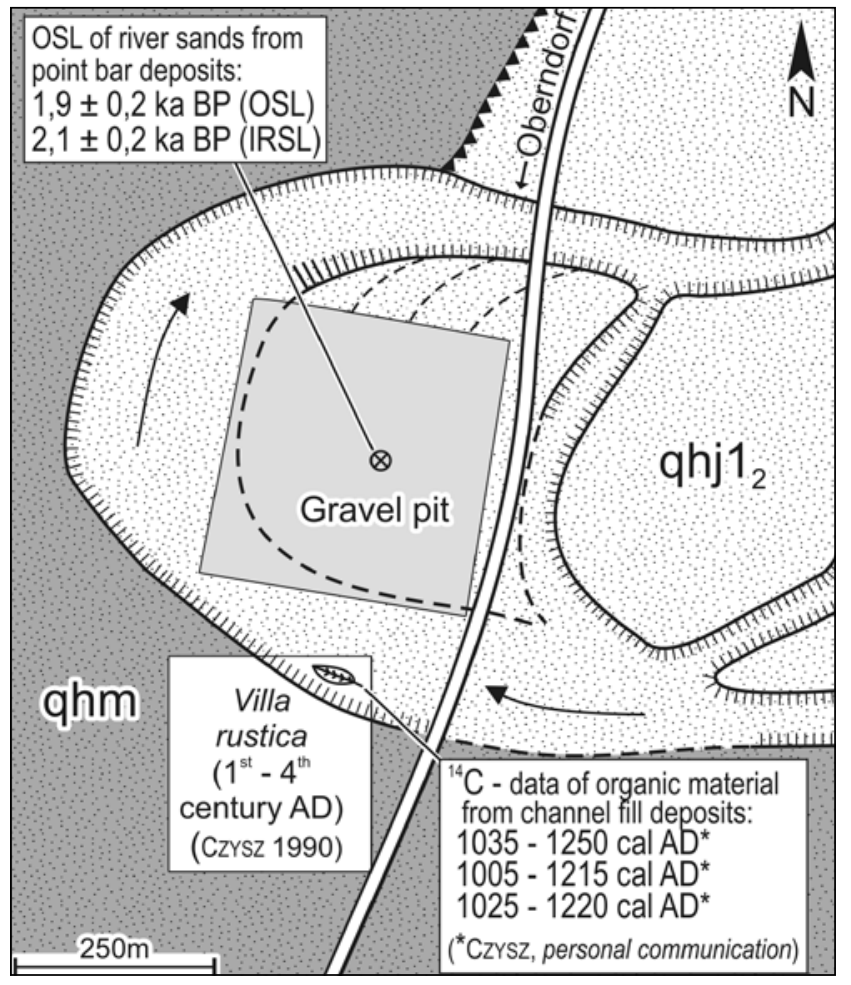

Fig. 6: Location of dated samples from the paleao-meander of the river Lech at the Roman villa rustica and in the gravel pit Oberndorf.

Abb. 6: Lage der Datierungen aus dem Bereich des Lech - Paläomäanders an der römischen Villa rustica und in der Kiesgrube Oberndorf.

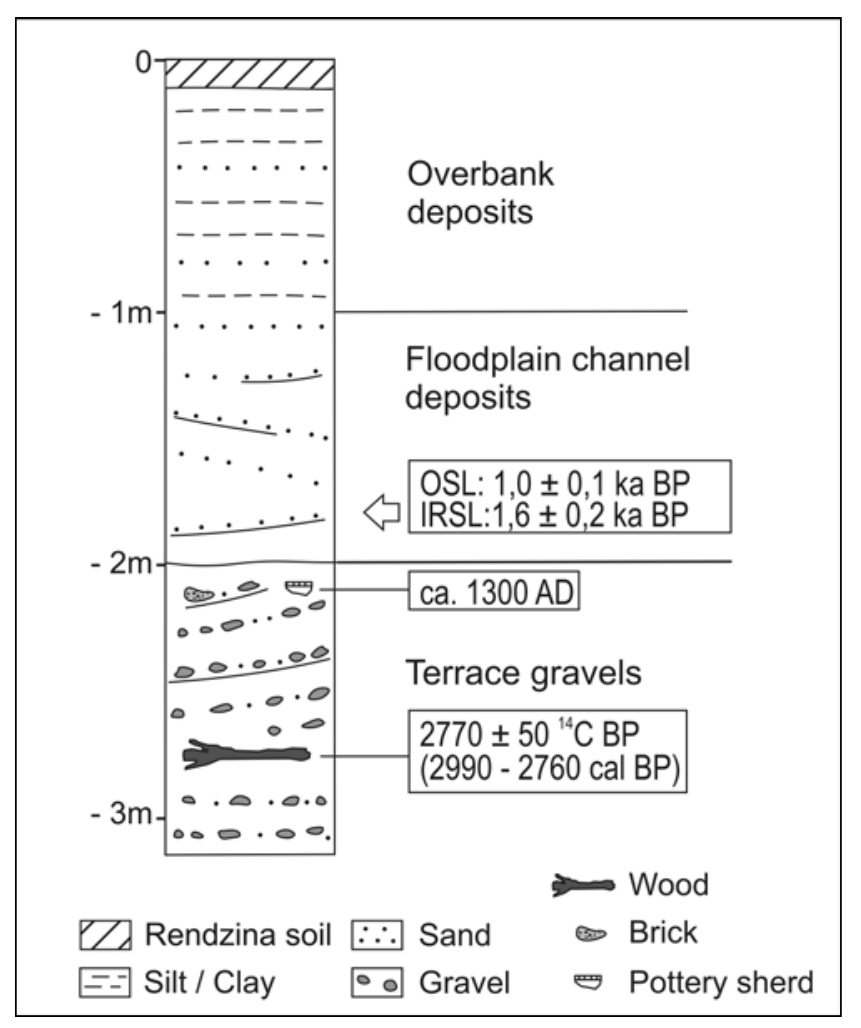

Fig. 7: Profile of one Subatlantic terrace $\left(q h j 2_{2 a}\right)$ at the gravel pit Reichertswert.

Abb. 7: Profil einer subatlantischen Terrasse $\left(q h j 2_{2 a}\right)$ in der Kiesgrube Reichertswert. of fine-grained sediments and peat in the gravel deposits as well as ${ }^{14} \mathrm{C}$-dated tree trunks of Preboreal age indicate the division of the gravel deposits (Fig. 2, 3, Tab. 1). It may be assumed that the Subatlantic terraces are often stacked on (or nested in) an older gravel body. The thickness of covering floodplain deposits varies from a few decimetres to several metres in filled channels.

Two terrace levels of early Subatlantic age $\left(q h j 1_{1}, q h j 1_{2}\right)$ have medieval settlements on their surface. A wood fragment retrieved from a depth of $5 \mathrm{~m}$ at the gravel pit Lindensee (Fig. 1) in the Lech valley yielded an age of $2450 \pm 50{ }^{14} \mathrm{C}$ BP (2730-2350 cal BP) and places the formation of the qhj1 - terrace to the Iron Age. Close to gravel pit Oberndorf a paleomeander of the Lech has eroded parts of a Roman villa rustica, originally situated on the Subboreal terrace (Fig. 1, 6). Dendrochronological data time the occupancy of the estate to between the $1^{\text {st }}$ and the $4^{\text {th }}$ century AD (Czysz 1990). ${ }^{14} \mathrm{C}$-dating of plant material from the meander channel fill (Czysz, personal communication) yielded ages of cal AD 1035-1250, cal AD 1005-1215 and cal AD 1025-1220. This channel was filled during floods, after the Lech cut off the meander. The terrace gravels in the inner bend of the paleomeander predate the channel fill ages, and likely span some centuries of point bar build out. This estimation is confirmed by luminescence ages of $1.9 \pm 0.2 \mathrm{ka} \mathrm{BP}$ (OSL) and 1.6 $\pm 0.2 \mathrm{ka} \mathrm{BP}$ (IRSL), which were sampled in the gravel body $300 \mathrm{~m}$ inbound from the paleomeander (LomAX $\&$ SchiELEIN, accepted). Thus, the formation of the $q h j 1_{2}-$ terrace took place during the Roman period.

On all younger Subatlantic terraces no superficial archaeological data is available. Due to the lack of outcrops on the older qhj2 - terrace it can only be dated by relative age estimations. The younger $q h j 2_{2 a}$ - terrace is well exposed at the gravel pit Reichertswert in the Danube valley upstream of the confluence (Fig. 1, 7). Here, the sandy gravels are epsilon cross-bedded, indicating the lateral accretion by a meandering Danube. Inside the gravel body several rounded brick fragments and a pottery sherd were found. The latter was dated to about $1300 \mathrm{AD}$ by H. Losert (Medieval and Postmedieval Archaeology, University of Bamberg). A tree trunk, excavated in c. $3 \mathrm{~m}$ depth in the gravel deposits below ground water level, yielded an age of $2770 \pm 50{ }^{14} \mathrm{C}$ BP $(2980-2760$ cal BP $)$. It can be assumed that this older trunk was relocated during medieval river activity. The qhj2 $2_{2 a}$ - terrace is covered by floodplain deposits formed of overbank fines and a sand-striped channel deposit sensu Schirmer (1995). A sample for luminescence dating was taken from these floodplain deposits. The quartz and the feldspar fraction are slightly overestimated compared to the recovered pottery (LOMAX \& SCHIELEIN, accepted). A trunk from the gravel pit Niederschönenfeld (Fig. 1), dated to $510 \pm 50{ }^{14} \mathrm{C} \mathrm{BP}(\sim 650-480$ cal BP $)$, supports a Late Medieval age of the qhj2 $2_{2 a}$ - terrace (Tab. 1).

The $q h j 2_{2 a}$ and $q h j 3$ - terraces feature no evaluable outcrops, because of the low altitude of the terrace surfaces above ground water level. Both terraces can be well dated by historical maps. The $q h j 2_{2 a}$ - terrace was deposited in the $17^{\text {th }}$ and $18^{\text {th }}$ century, the $q h j 3$ - terrace since about $1800 \mathrm{AD}$. In addition, the maps from the $19^{\text {th }}$ century enable the analysis of channel patterns of both rivers (Schielein 2010, Fig. 8). The Danube shows the typical pat- 
tern of a meandering river, whereas the Lech can be designated as an anabranching river sensu BRICE (1983) with numerous bifurcations but also several meander loops. Downstream of the Lech - Danube confluence the channel pattern of the modern Danube River is a transitional one between both river patterns. Since the regulation of the river channels around $1900 \mathrm{AD}$ and the construction of many dams in the 1950s the natural fluvial dynamics of both rivers as well as the formation of terraces has been more or less eliminated.

\section{Discussion}

The study of the terrace composition at the Lech - Danube confluence yielded a sequence of one Würmian Lateglacial and eight Holocene terraces. The comparison of this sequence of river terraces with other valleys in the Northern Alpine Foreland indicates that their development has not only a local character but is influenced by supraregional driving mechanisms. Finally, the possibilities of reconstructing changes of parameters in time like the volumina of fluvial deposits, the level of the base and top of river bed deposits and the channel geometry will be discussed for the study area.

The Würmian Lateglacial Niederterrasse is only preserved in the Danube valley downstream of the Lech Danube confluence. Its base level is several meters higher than that of Holocene gravel deposits. A similar observation for all Niederterrassen was also made by ScHELLMANN (1990) in the Danube valley downstream of Regensburg. The Niederterrasse in the study area corresponds most likely to that of the Stufe von Friedheim, the latest Lateglacial Niederterrasse at the middle reaches of the Lech (GESSLEIN \& SchellmanN 2010), to that of the Lateglacial NT 3 in the Danube valley downstream of Regensburg (e.g. Schellmann 2010) and to the NT 3 in the Isar valley (e.g. Schellmann et al. 1994). In the Danube valley downstream of the narrow valley (Steppberg - Neuburger Talenge), extensive areas of Niederterrassen are related to the Pleni- and Lateglacial (KLeinschnitz \& Kroemer 2001). In contrast, at the Lech - Danube confluence further terraces of Late- or Pleniglacial age are missing, although a former distribution over the entire valley floor is very likely. The minor occurrence of Niederterrassen here results from erosion and reworking of older deposits during the Early Holocene due to the widespread lateral activity of the river Lech.

Preboreal river bed deposits beneath Subboreal to Subatlantic terraces extend over great parts of the investigated valley floors. Due to their vast extension it can be assumed that these underlying gravels were deposited in several reworking phases during the Preboreal, in which the river beds of Lech and Danube were relocated and possibly deposited several terraces. The base of these Preboreal gravels lies deeper than that of any other Quaternary river deposits in the study area (Fig. 2, 3). Concluding, the maximum rate of incision was reached at the change of Younger Dryas to the Preboreal or in the early Preboreal. This conclusion is also true for the Danube valley downstream of Regensburg (SCHELLMANN 2010) and for the confluence of Iller and Danube (Graul \& Groschopf 1952). An underly-

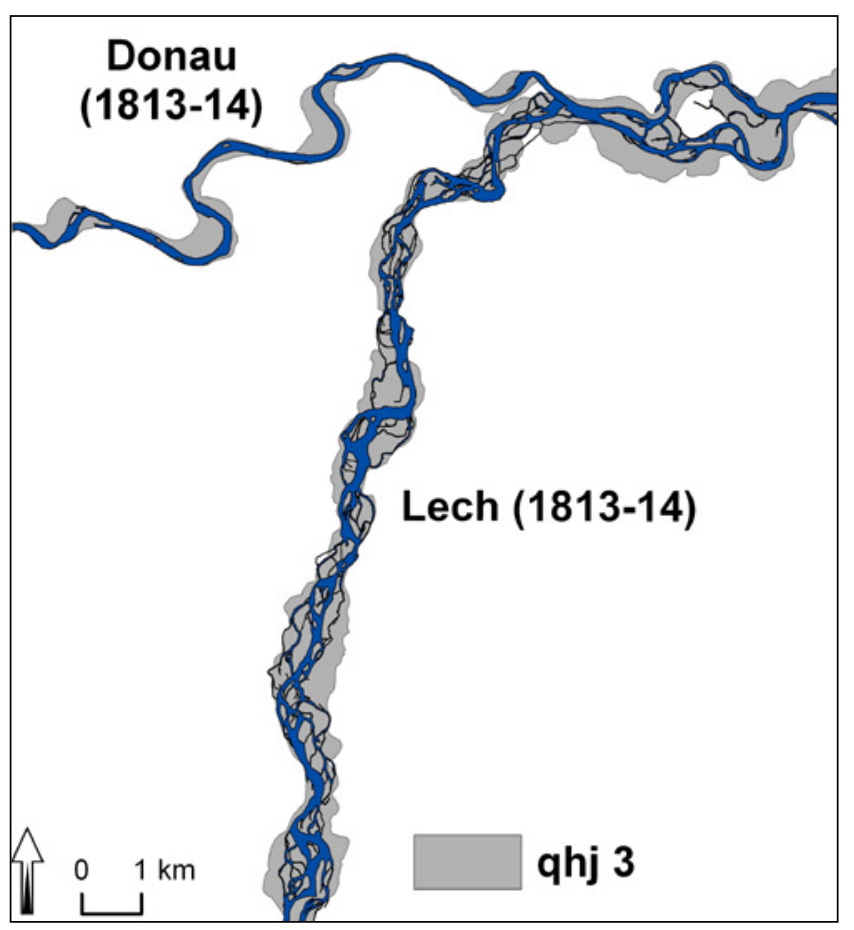

Fig. 8: Historical river channel patterns of Lech and Danube (SCHIELEIN 2010). Abb. 8: Historische Flussläufe von Lech und Donau (SCHIELEIN 2010).

ing gravel deposit beneath a Subboreal Iller terrace at the Iller - Danube confluence has been dated by BECKER (1982) to the Preboreal. These deposits indicate the reworking of older fluvial deposits in the Preboreal during which the base level of erosion was significantly lower than in subsequent phases of the Holocene and most probably in the Pleistocene. Preboreal terraces are morphologically prevalent in the middle Lech valley (GESsLEIn \& ScheLLMANN 2010) and in the valleys of Isar (e.g. SchellmanN 1990, Feldmann 1990, Schellmann et al. 1994), Danube (e.g. Schellmann 2010, 1990) and Inn (Megies 2005). Due to their marginal morphological preservation in the study area, no statements about the channel geometry of the Preboreal terraces are possible.

The Atlantic period is not represented by river channel deposits in the investigated area. However, terraces of this age are well preserved in the middle Lech valley (Gesslein \& SchellmanN 2010), in the Danube valley downstream of Regensburg (e.g. Schellmann 2010, 1990) and in the Isar valley (e.g. Schellmann 1990, Feldmann 1990, SchellmanN et al. 1994). It is conceivable that terraces of Atlantic age in the study area were eroded afterwards.

The Subboreal terrace is the most prominent one in the study area. Its deposition is well dated to between $\mathrm{c}$. $4000{ }^{14} \mathrm{C}$ BP ( 5040-3780 cal BP) and the Roman period. The terrace has probably been deposited in several phases during the Subboreal, which are represented by gravel deposits building up different ridges within this terrace. Yet, these deposits could not be chronologically differentiated due to the lack of numerical ages from different ridges. Remarkably, Gesslein \& Schellmann (2010) differentiated four Subboreal terraces with a relatively small extent compared to the other Holocene terraces at the Lech upstream of Ausgburg. A connection of the terraces between 
the lower and the middle reaches of the Lech valley has not been achieved so far. An extensive terrace of Subboreal age at the Iller - Danube confluence has already been described by Graul \& Groschopf (1952), which they constituted as an alluvial fan (Iller Schwemmkegel). BEcKer (1982) verified their age assumption by dating numerous oak trunks, of which the bigger part yielded dendrochronological ages between 2300 and $1600 \mathrm{BC}$. Thus, the accumulation of the lller Schwemmkegel corresponds to the Subboreal terrace at the Lech - Danube confluence. In addition, a Subboreal terrace exists at the lower Isar valley (SCHELLmANN 1990) and the adjacent Danube valley (Schellmann 1990, 2010). But in contrast to these terraces, the base level of the Subboreal terrace in the study area lies several meters higher than that of the Preboreal gravel deposits. The few channels on the Subboreal ridges are mainly meander-shaped but also show some bifurcations (Fig. 1). The broad depressions on the Subboreal terrace are filled with floodplain deposits and therefore do not allow statements about the channel pattern within.

During the Subatlantic period, six terraces were deposited in the lower Lech valley and in the Danube valley downstream of the confluence, but only four terraces upstream. The number of Subatlantic terraces in the lower Lech valley is not only higher than at the Danube valley upstream of the confluence but also higher than in the middle Lech valley (Gesslein \& Schellmann 2010). At the lower Isar valley (Schellmann 1990) and at the Danube downstream of the study area (Kleinschnitz \& Kroemer 2001, Schellmann 1990) also four Subatlantic terraces were distinguished. The reason for the larger amount of Subatlantic terraces at the lower Lech valley might be both a local characteristic and/or a missing morpho- and chronostratigraphical differentiation of these terrace remnants elsewhere. Recently, Schellmann (2010) showed that the oldest of four Subatlantic terraces in the Danube valley near Straubing, the H4-Terrace, can be subdivided into two separate terraces; one deposited during the late Subboreal between c. 2900 to $2500{ }^{14} \mathrm{C}$ BP and one during the Roman Period between 2200 to $1500{ }^{14} \mathrm{C}$ BP. All Subatlantic terraces are incised in older Holocene deposits, but do not reach the base level of the partly underlying gravel deposits of older Holocene age.

The morphology of all Subatlantic terraces at the Danube upstream and of the four oldest Subatlantic terraces downstream of the confluence is typically formed by a meandering river. At the lower Lech the oldest four Subatlantic terraces clearly show meandering, but in parts also anabranching channel patterns. The youngest Subatlantic terrace ( $q$ hj3) in the Lech valley is dominated by an anabranching pattern, as indicated by terrace morphology and by historical maps. The $q h j 3$ - terrace of the Danube downstream of the confluence is influenced by the Lech River, whereas historical maps show a typical meandering channel pattern of the Danube river upstream of the confluence. The reasons for the differences in channel pattern (meandering vs. anabranching) of the rivers Lech and Danube, as reconstructed for the Subatlantic, might be explained by the different valley gradients. The relatively low gradient in the Danube valley $(0.7 \%$ ) as well as a balanced discharge typically result in a meandering channel pattern according to LEOPOLD \& WOLMAN (1957). In con- trast, the lower Lech valley has a larger gradient $(1.4 \%$ ) and the Lech features infrequent but high peak discharges and strong flood events during modern age. Therefore, a higher sediment load of the Lech than of the Danube can be assumed, which may cause increased sediment deposition at the confluence point. As a result, the stream of the Danube downstream of the confluence splits in multiple branches. This process may be intensified through the restricting effect of the Danube before entering the narrow valley east of the study area. Here, the valley width reduces from approximately 5 to a minimum of $0.5 \mathrm{~km}$.

In addition to the performed Late Quaternary reconstruction of valley development at the Lech - Danube confluence, a summary of the benefits of different fluvial parameters at the study area is given: As the former extent of a terrace is often difficult to reconstruct due to later erosion, the width of the former river bed and hence volumina calculations are only reliable, if the external borders of a terrace are preserved on both sides of a valley. In the study area this is only suitable for single terraces in limited valley sections and therefore precludes the comparison of sedimentation rates over the Late Quaternary. The base and top levels of terrace gravels provide the maximum depth of former river beds and the rate of incision in older deposits. In the study area, the base of all Holocene deposits is deeper than that of the Würmian Lateglacial Niederterrasse, reaching its maximum depth beneath Preboreal deposits. The Subboreal terrace lies widespread on these Preboreal deposits, whereas all Subatlantic terraces are incised in older deposits. The channel morphology documents the channel pattern during terrace deposition. As former channel patterns are morphologically not well preserved on older terraces, the analysis of channel geometry was only useful for Subatlantic terraces, especially for the two youngest terraces, whose channel patterns are pictured in historical maps.

\section{Conclusion and outlook}

A chronostratigraphy of one Würmian Lateglacial and up to eight Holocene terraces at the confluence of the Lech and Danube valleys was established. Pleni- and Lateglacial terraces were almost completely eroded during the Preboreal. An evidence of the Preboreal reworking phase is a widespread gravel deposit beneath younger terraces. Atlantic terraces are not preserved. They were most likely eroded during the Subboreal. The Subboreal terrace is the most extensive one at the Lech - Danube confluence and was deposited over a long period of several thousand years, possibly in several phases. During the Subatlantic a sequence of up to six terraces was deposited in the study area. The morphology of the youngest Subatlantic terraces as well as historical maps of Modern age indicate a difference in channel geometry between the Lech (anabranching) and the Danube upstream of the confluence (meandering). Downstream of the Lech - Danube confluence the Subatlantic terrace morphology and historical maps refer to a transitional channel pattern between meandering and anabranching.

In future, the river deposits in the Lech valley upstream of the confluence will be investigated in order to 
find Pleniglacial and possibly more Holocene terraces. Moreover, we aim to get a connection to the study area of GESSLEIN \& SCHELLMANN (2010) at the middle reaches of the Lech valley. Further investigations about the dating of Late Quaternary as well as Middle Pleistocene fluvial deposits are in progress.

\section{Acknowledgements}

The study was funded by the Bavarian Environmental Agency (Bayerisches Landesamt für Umwelt, LFU. Munich, Germany). The authors would like to thank G. Doppler, E. Kroemer and B. Gesslein for helpful comments and discussions in the field as well as F. Preusser and M. Fiebig for support of OSL dating. We also thank K. Cohen and two anonymous reviewers for detailed and very helpful comments and improvements of this article.

\section{References:}

Becker, B. (1982): Dendrochronologie und Paläoökologie subfossiler Baumstämme aus Flußablagerungen. - Ein Beitrag zur nacheiszeitlichen Auenentwicklung im südlichen Mitteleuropa. - Mitteilungen der Kommission für Quartärforschung der Österreichischen Akademie der Wissenschaften 5.

BRICE, J. (1983): Planform properties of meandering rivers. In: ELLIOT, C. (ed.): River meandering. Proceedings of the October 24-26 Rivers 83'Conference, ASCE, New Orleans: 1-29.

Bronk RAmsey, C. (1995). Radiocarbon calibration and analysis of stratigraphy: The OxCal program. Radiocarbon, 37(2): 425-430.

Brunnacker, K. (1957): Die Geschichte der Böden im jüngeren Pleistozän in Bayern. - Geologica Bavarica, 34.

Czysz, W. (1990): Ausgrabungen in einem römischen Gutshof bei Oberndorf a. Lech. - Das archäologische Jahr in Bayern 1989: 133-140.

FELDmANN, L. (1990): Jungquartäre Gletscher- und Flußgeschichte im Bereich der Münchener Schotterebene. - Diss. Universität Düsseldorf: 355 S

Fiebig, M. \& Preusser, F. (2003): Das Alter fluvialer Ablagerungen aus der Region Ingolstadt (Bayern) und ihre Bedeutung für die Eiszeitenchronologie des Alpenvorlandes. - Zeitschrift für Geomorphologie, N.F., 47/4: 449-467, Berlin.

Gesslein, B. \& Schellmann, G. (2010): Zur Stratigraphie und Altersstellung der jungquartären Lechterrassen zwischen Kinsau und Prittriching erste Ergebnisse. - Bamberger Geographische Schriften 24: 189-213.

Graul, H. (1943): Zur Morphologie der Ingolstädter Ausräumungslandschaft. Die Entwicklung des unteren Lechlaufes und des Donaumoosbodens. - Forschungen zur Deutschen Landeskunde, 43: 1-114, Heidelberg.

Graul, H. \& Groschopf, P. (1952): Geologische und morphologische Betrachtungen zum Illerschwemmkegel bei Ulm. - 5. Bericht der Naturforschenden Gesellschaft. Augsburg, S. 3-27.

Grottenthaler, W. (unpublished): Geologische Manuskriptkarte zum Blatt 7231 Genderkingen. München (Bayerisches Landesamt für Umwelt).

HND (2010): Hochwassernachrichtendienst Bayern. www.hnd.bayern.de.

Homilius, J., Weinig, H., Brost, E., BAder, K. (1983): Geologische und geophysikalische Untersuchungen im Donauquartär zwischen Ulm und Passau. - Geologisches Jahrbuch, E 25: 3-73, Hannover.

KLASEN, N. (2008): Lumineszenzdatierung glazifluvialer Sedimente im nördlichen Alpenvorland. - Inaug.-Diss., Universität zu Köln.

Kilian, R. \& Löscher, M. (1979): Zur Stratigraphie des Rainer Hochterrassen-Schotters östlich des unteren Lechs. - Sammlung quartärmorphologischer Studien II, Heidelberger Geographische Arbeiten, 49: 210-217.

Kleinschnitz, M. \& Kroemer, E. (2001): Geologische Karte von Bayern 1:25 000, Erläuterungen zum Blatt Nr. 7233 Neuburg a. d. Donau. 40 S., München (Bayerisches Geologisches Landesamt).
Kock, S., Huggenberger, P., Preusser, F., Rentzel, P., Wetzel, A (2009a): Formation and evolution of the Lower Terrace of the Rhine River in the area of Basel. - Swiss Journal of Geosciences 102: 307-321. Kock, S., Kramers, J., Preusser, F., Wetzel, A., (2009b): Dating of Late Pleistocene terrace deposits of the River Rhine using uranium series and luminescence methods: potential and limitations. - Quaternary Geochronology 4, 363-373.

Leopold, L. B. \& Wolman, M. G. (1957): River Channel Patterns: Braided, Meandering and Straight. Geological Survey Professional Paper 282-B.

LOMAX, J. \& SCHIELEIN, P. (accepted): Testing OSL-dating on different fluvial deposits of Holocene age from the Lech and Danube valley. Accepted for publication for Quaternary Geochronology.

Mangerud, J., Andersen, S.T., Berglund, B.E., Donner, J.J. (1974): Quaternary stratigraphy of Norden, a proposal for terminology and classification - Boreas 3: 109-128.

Megies, H.: Kartierung, Datierung und umweltgeschichtliche Bedeutung der jungquartären Flussterrassen am untere Inn - Heidelberger Geographische Arbeiten 120.

MünZBERger, P. (2005): Jungquartäre Talgeschichte der Donau und ihrer Nebenflüsse im Raum Straubing - Deggendorf in Abhängigkeit von natürlichen und anthropogenen Einflüssen. - Regensburger Beiträge zur Bodenkunde, Landschaftsökologie und Quartärforschung 8.

Murray A.S., Wintle, A.G. (2000): Luminescence dating using an improved single-aliquot regenerative-dose protocol. - Radiation Measurements 32: 57-73.

PENCK, A (1882): Die Vergletscherung der Deutschen Alpen, ihre Ursachen, periodische Wiederkehr und ihr Einfluss auf die Bodengestaltung. - 483 S.; Leipzig (Barth).

Penck, A. \& Brückner, E. (1909): Die Alpen im Eiszeitalter. - 3 Bde.: 1199 S.; Leipzig (Tauchnitz).

Reimer, P. J., BAillie, M. G. L., Bard, E., Bayliss, A., Beck, J. W., Bertrand, C., Blackwell, P. G., Buck, C. E., Burr, G., Cutler, K. B., Damon, P. E., Edwards, R. L., Fairbanks, R. G., Friedrich, M., Guilderson, T P., Hughen, K. A., Kromer, B., McCormac, F. G., Manning, S., Bronk Ramsey, C., Reimer, R. W., Remmele, S., Southon, J. R., Stuiver, M. Talamo, S., Taylor, F. W., van der Plicht, J., Weyhenmeyer, C. E. (2004): IntCal04 Terrestrial radiocarbon age calibration, 0-26 cal kyr BP. - Radiocarbon 46:1029-1058.

Schaefer, I. (1966): Der Talknoten von Donau und Lech. - Mitteilungen der Geographischen Gesellschaft in München, 51: 59-111.

Schellmann, G. (1990): Fluviale Geomorphodynamik im jüngeren Quartär des unteren Isar- und angrenzenden Donautales. - Düsseldorfer Geographische Schriften, 29.

Schellmann, G. (2010): Neue Befunde zur Verbreitung, geologischen Lagerung und Altersstellung der würmzeitlichen (NT 1 bis NT3) und holozänen (H1 bis H7) Terrassen im Donautal zwischen Regensburg und Bogen. - Bamberger Geographische Schriften 24: 1-77.

Schellmann, G., Becker, B., Feldmann, L. \& Kromer, B. (1994): Absolute Daten zur spätglazialen und altholozänen Flußgeschichte an der Isar. - Düsseldorfer Geographische Schriften, 34: 79-94.

Schielein, P. (2010): Neuzeitliche Flusslaufverlagerungen des Lechs und der Donau im Lechmündungsgebiet - qualitative und quantitative Analysen historischer Karten. - Bamberger Geographische Schriften 24: 215-241.

Schirmer, W. (1983): Die Talentwicklung an Main und Regnitz seit dem Hochwürm. - Geologisches Jahrbuch, A 71: 11-73.

Schirmer, W. (1995): Valley bottoms in the late Quaternary. - Zeitschrift für Geomorphologie, Neue Folge, 100 (supplement): 27-51.

Schreiber, U. (1985): Das Lechtal zwischen Schongau und Rain im Hoch-, Spät- und Postglazial. - Geologisches Institut der Universität zu Köln, Sonderveröffentlichungen, 58.

Streit, R. (Hrsg.) (1978): Geologische Karte von Bayern 1:25 000, Erläuterungen zum Blatt Nr. 7232 Burgheim Nord. - 222 S., München (Bayerisches Geologisches Landesamt).

Tillmanns, W., Münzing, K., Brunnacker, K. ひ Löscher, M. (1982): Die Rainer Hochterrasse zwischen Lech und Donau. - Jahresberichte und Mitteilungen des Oberrheinischen Geologischen Vereines, 64: 79-99.

Wallinga, J., Murray, A.S., Wintle, A.G., (2000): The single-aliquot regenerative-dose (SAR) protocol applied to coarse-grain feldspar. Radiation Measurements 32: 529-533 